DOI: https://doi.org/10.24867/09DS02Sandic

\title{
ПРИСТУПАЧНОСТ ОСОБА С ПОСЕБНИМ ПОТРЕБАМА НА ТЕРИТОРИЈИ ГРАДА НОВОГ САДА
}

\section{ACCESSIBILITY OF DISABLED PEOPLE IN NOVI SAD}

\author{
Боривој Сандић, Факултет техничких наука, Нови Сад
}

\section{Област - САОБРАһАЈ}

Кратак садржај - Утврђивање мобилности особа са посебним потребама, као и предлог мера за повећање и побољшање приступачности и мобилности особа са посебним потребама у саобраћају.

Кључне речи: пристпачност, особе са посебним потребама, мобилност (број путовања).

Abstract - In this paper was determined the mobility of persons with special needs, as well as proposing measures to increase and improve the accessibility and mobility of persons with special needs in traffic.

Keywords: accessibility, people with special needs, mobility (number of trips).

\section{1. УВОД}

Тема мастер рада је посвећена особама с посебним потребама и њиховом кретању и унапређивању кретања у саобраћају. Људи с функционалним сметњама представљају једну од посебних група становништва којој, приликом планирања и обликовања окружења, треба да се посвети посебна пажња.

Укључивање таквих људи у свакодневни живот пре свега зависи од изграђеног окружења, које за њих може представљати препреку. Због таквих препрека су особама са физичким хендикепом ускраћена њихова животна права, јер се практично свуда сусрећу с несавладивим тешкоћама.

За особе с функционалним сметњама проблем пре свега представља неприступачност изграђеног окружења, због чега су њихов свакодневни живот и мобилност у знатној мери отежани. Под појмом изграђено окружење се подразумева уже стамбено окружење, као и шире стамбено, животно, радно, саобраћајно или рекреативно окружење.

Препреке које особама с функционалним сметњама стварају тешкоће се могу поделити на препреке настале код обликовања спољашњег простора и препреке настале код обликовања унутрашњег простора или друге архитектонске препреке.

Подаци о броју путовања добијени су на основу реалног истраживања методом анкетирања непосредних испитаника на територији града Новог Сада [1].

\section{НАПОМЕНА:}

Овај рад проистекао је из мастер рада чији ментор је била др Валентина Мировић, ванр. проф.

\section{2. СПОСОБНОСТ КРЕТАЊА ГЛАВНИХ ГРУПА ОСОБА С ФУНКЦИОНАЛНИМ СМЕТЬАМА ПРЕМА ПОСТОЈЕЪИМ ПУТНО- САОБРАЋАЈНИМ УСЛОВИМА}

Стамбена подручја и готово сви објекти јавне намене у великој мери се прилагођавају захтевима физичког окружења особама са посебним потребама. Они углавном немају тешкоћа код кретања унутар својих домова. Међутим, оне наступају чим напусте своје станове, јер су препреке присутне на путевима, трговима, као и другим јавним површинама. Проблематични су пре свега путни ивичњаци, саобраћајна острва, подземни и надземни пролази и паркинг простори. Такође, проблем представља организација јавног путничког саобраћаја због денивелисаних стајалишта или станица, као и улазак у возила и излазак из њих. Главне групе особа с посебним потребама су:

Особе с потпуним или делимичним оштећењем вида

Особе у инвалидским колицима

Особе са ограниченом способношћу кретања

Особе с потпуним или делимичним оштећењем слуха

Путна инфраструктура треба да буде уређена тако да омогућава прилаз и приступ, као и заустављање и паркирање. Потребама особа с функционалним сметњама треба да се прилагоде и подземни и надземни пролази, мостови, путеви, раскрснице и пешачки прелази. Једну од већих препрека за особе функционалним сметњама представља коришћење јавног путничког саобраћаја. Највише тешкоћа у превозу са средствима јавног саобраћаја имају људи који се отежано крећу или они који уопште не могу да се крећу и користе инвалидска колица. Слабовиде и слепе особе могу да користе средства јавног саобраћаја уколико су она на одговарајући начин прилагођена њиховим потребама [3].

Планирање пута за особе с функционалним сметњама зависи од изграђености окружења (тротоари, ходници, пасажи, надземни и подземни пролази, паркови и сл.), препрека у изграђеном окружењу (степениште, косе рампе, рекламне табле, жардињере за цвеће и сл.) и од проблема који су повезани са конфигурацијом терена [3].

\section{3. ИСТРАЖИВАЊЕ}

Истраживање о приступачности особа са инвалидитетом је спроведено на целокупној територији града Новог Сада, обухватајући све главне 
делове града односно њихове најзначајније путне правце по којим се особе са посебним потребама најчешће крећу. Истраживање је спроведено у виду анкете тј. упитника са питањима о изворним и циљним путовањима особа са посебним потребама, сврси путовања, виду превоза, врсти инвалидитета, полу, старости итд.

Главни циљ овог задатка је било утврдити мобилност (број путовања) особа са посебним потребама по врсти инвалидитета, сврси путовања и виду превоза. У истраживању је учествовало 448 испитаника у току радног дана и 337 испитаника у току нерадног дана. Под радним данима се подразумева анкетирање особа са посебним потребама уторком, средом или четвртком.

Под нерадним данима се мисли на дане викенда, тј. субота или недеља. Најмлађи учесник у овој анкети је имао 7 година, а најстарији учесник 86 година старости. Број путовања за радни дан износи 1183, а за нерадни дан 773.

На основу обраде података из табеле утврђено је да мобилност особа са посебним потребама у току радног дана износи 2,64 путовања по становнику на дан, а мобилност у току нерадног дана износи 2,30 путовања по становнику на дан.

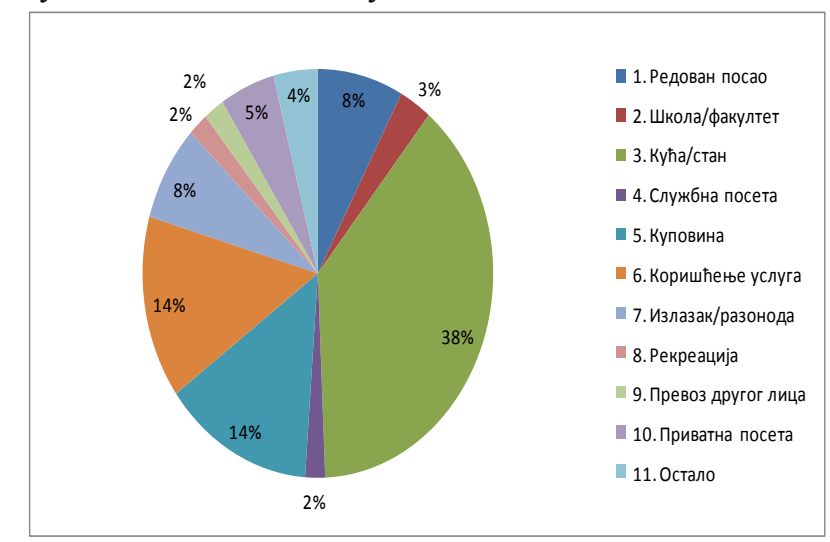

График бр. 1. Број путовања по сврси путовања у току радног дана

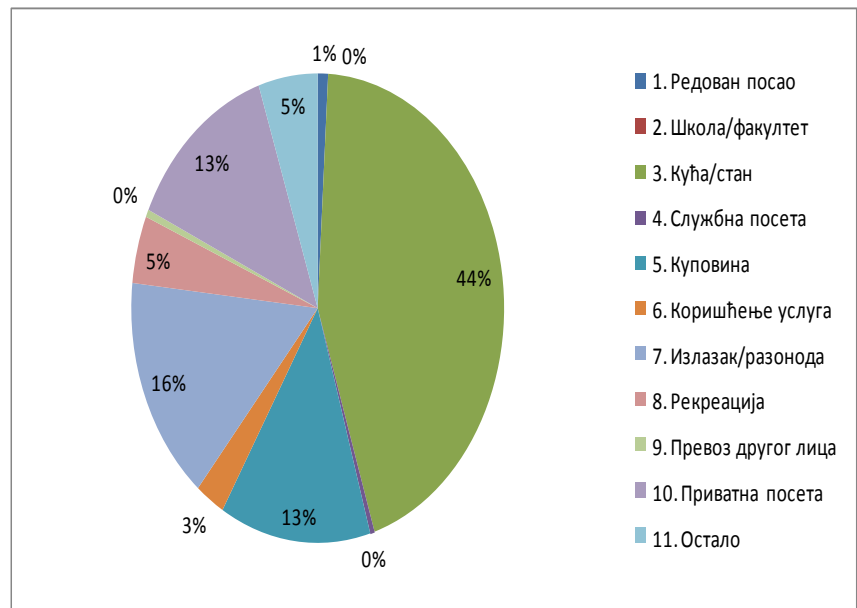

График бр. 2. Број путвања по сврси путовања у току нерадног дана

Главни задаци Тима за приступачност у оквиру стратегије приступачности града Новог Сада су побољшање и унапређење:
1. Јавног простора и јавног превоза

2. Објекта намењених за јавну употребу

3. Информација и комуникација

\section{4. ТЕХНИЧКИ ЕЛЕМЕНТИ ПРОЈЕКТОВАЊА ПОВРШИНА}

Код планирања пешачке стазе треба имати на уму да je за одређену групу особа с функционалним сметњама потребна довољно широка стаза. Мере које су потребне за одређивање пешачке стазе с обзиром на групу особа с функционалним сметњама су приказане на следећој слици.

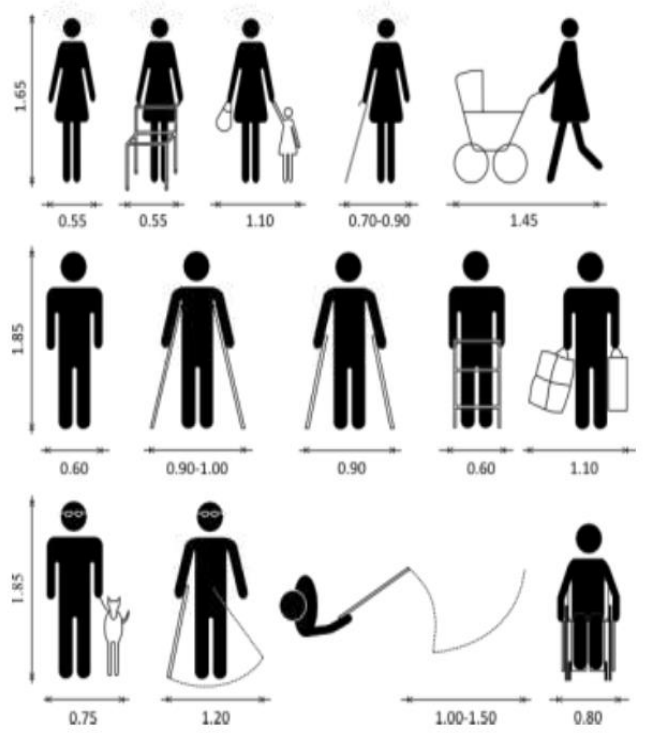

Фотографија бр. 1. Мере потребне за одређивање пешачке стазе

Употребљиве пешачке стазе су оне са уздужним нагибом мањим од 5\%, што значи нагиб 1:20. Стазе с већим нагибом се сматрају косинама. За људе у инвалидским колицима нагиб до $3 \%$ још увек не представља напор, код нагиба од 4-5\% на већим раздаљинама треба направити хоризонтално одмориште д $=150$ цм на растојању $30-50$ м. Стазе с већим нагибом се планирају само у изузетним случајевима због топографије терена. Попречни нагиб треба да буде до $2 \%$.

Површина не сме да буде клизава ни у условима сувог ни у условима мокрог времена, а спојеви морају бити углачани. Ивице треба да буду израђене тако да слепе особе могу да их напипају, што се постиже коришћењем различитих врста материјала или ивичњака. На пешачкој стази не треба да постоје препреке и висинска одступања канализационих шахтова, док решетке уливних сливника треба да се изведу искључиво правоугаоно на правац кретања. Када то не може да се избегне, слободно стојеће препреке у окружењу треба да се истакну с веома упадљивим бојама. Каналете могу да се користе и као линија водиља за слепе. Исто тако, пешачка стаза треба да буде добро и равномерно осветљена, на начин којим се спречава стварање рефлексије. 
Ако се средства расвете смисаоно поставе, могу служити и као оријентациона водиља. Код планирања пешачке стазе, веома значајну улогу има диференцијација саобраћаја. То значи да саобраћај пешака треба да се одвоји од моторног саобраћаја зеленом површином или бициклистичком стазом.

Такође, саобраћај пешака треба да се одвоји и од бициклистичког саобраћаја, с висинском разликом $\mathrm{h}=$ 3 цм. У простору до висине 220 цм и ширине 120 цм не смеју да буду присутне никакве препреке. У случају када то није изводљиво, контуре препреке морају бити препознатљиве на висини до 30 цм (слепе и слабовиде особе).

Препреке на пешачким површинама могу бити узбрдице, сужења, степенице, неправилно постављени саобраћајни и несаобраћајни знаци, стубови, дебла, висеће табле, тенде, гране, разни постављени или изграђени елементи (жардињере за цвеће, постоља за бицикла, граничници и сл.), неправилно изведени поклопци и решетке канализационих шахтова, паркирани аутомобили и друго [3].

\section{Подне коцке за вођење}

У обликовању јасно и недвосмислено обликованог окружења значајну улогу има једноставно пројектовање површина.

У том погледу нарочит значај има употреба различитих материјала за израду тла. Основни елемент у обликовању линија којима се усмеравају слепе односно слабовиде особе у простору чине подне коцке за вођење и коцке за обавештавање.

Уопштено се разликују коцке без тактилних жлебова (светле, тамне), тактилне коцке за вођење с рељефно избоченим равним линијама, тактилне коцке за обавештавање с рељефно избоченим пуним круговима и тактилне коцке за обавештавање с рељефно избоченим пуним квадратима [3].
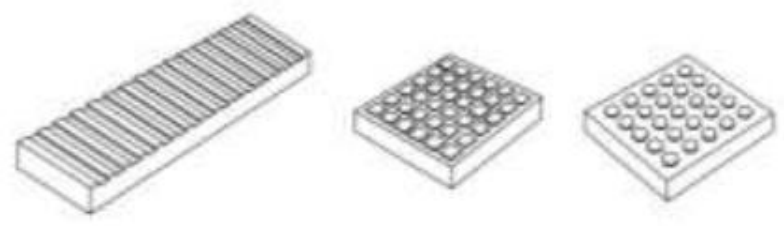

Фотографија бр. 2. Подне коике за вођење слепих особа

\section{5. ПРЕПОРУКЕ ЗА ПРИСТУПАЧНО ОКРУЖЕЊЕ}

Да би саобраћајнице биле приступачне, потребно је да постоји функционална веза између свих елемената од којих се састоје, као што су улични мобилијар, возила јер било који лоше постављен елемент (на пример, возило паркирано на тротоару) може, за неке људе, да представља несавладиву препреку.

Стога, осим подизања нивоа свести јавности о потреби да поштују намене одређеног простора, пројектовање улица и тротоара требало би да укључи и елементе које спречавају да се тај простор неправилно користи-наравно, увек обезбеђујући да ови елементи сами не представљају препреку [4].

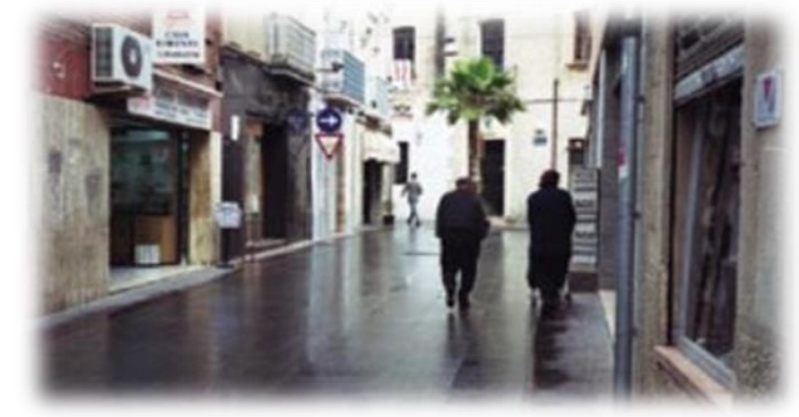

Фотографија бр. 3. Проширена улица

Значај глобалних система позицинирања за смањење препрека у кретању слепих и особа с тешким оштећењем вида

“Препреке" које отежавају кретање слепих и слабовидих особа узрокују пре свега проблеми у оријентацији и недостатак информација. На пример, виртуелно нема града који има адекватне мапе (рељефне мапе којима располаже мали број градова у ствари су виртуелно неупотребљиве за већину особа којима су намењене). Оријентацију на путу отежава чињеница да саобраћајни знаци нису приступачни за слепе и особе са тешким оштећењем вида. Постојећи приступи решењима ограничени су на појединачне линије водиље за слепе које су постављене уз ивице појединачних железничких перона и звучне саобраћајне опреме на семафорима, које служе да се избегне опасност. Сателитски навођен навигациони систем (ГПС) опремљен синтетајзером гласа омогућио би распознавање и објављивање тренутног положаја у граду, али корисник и даљене би располагао никаквом информацијом о томе коју путању да користи.

\section{Одржавање улица}

Пројекат улица и урбаних елемената који се на њима налазе дефинише степен приступачности улице. Чак и ако је пројекат добар, повремено се дешава дарадови на одржавању илинедостатак одржавања озбиљно утичу на приступачност.

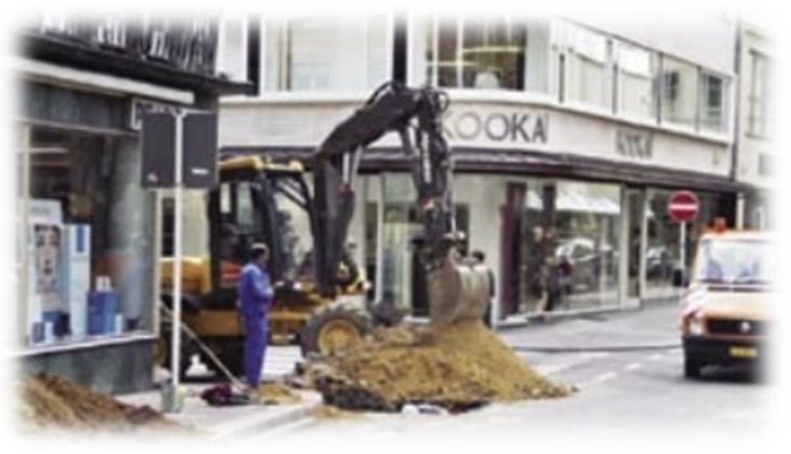

Фотографија бр. 4. Лоче заштићени радови

\section{Јавни превоз}

Било да је то из потребе или за разоноду, кретање и стизање од једног места до другог карактеристика је људских бића. Уколико тој потреби додамо све распрострањенију друштвену идеологију личне 
аутономије, постаје јасно да свако путовање у животу мора да буде приступачно. Јавни превоз има веома значајну улогу у остваривању тог циља, и стога мора да узме у обзир разноликост становништва (приступачност), да покрије потребе свих за кретањем (ефективност), да буде компатибилан са окружењем (очување околине), и да буде одржив [4].

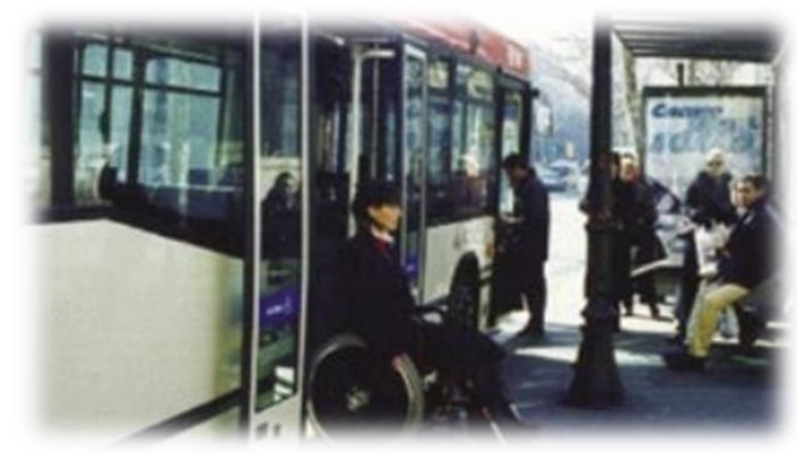

Фотографија бр. 5. Олакшан улазак/излазак из јавног превоза за особе у инвалидским колицима

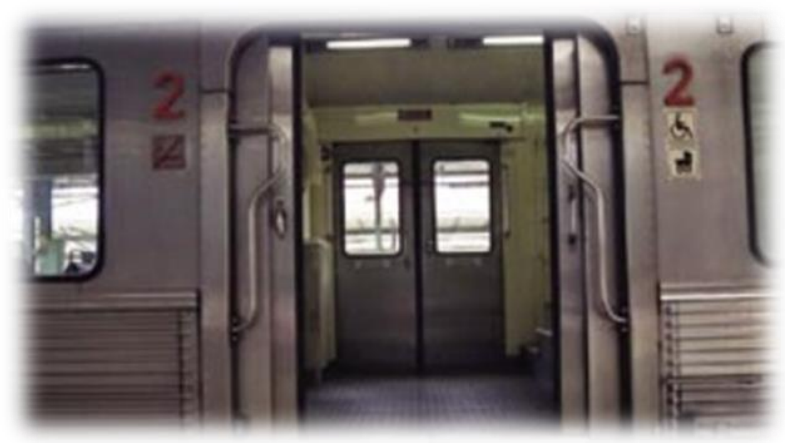

Фотографија бр. 6. Улаз у истом нивоу

\section{6. ЗАКљУЧАК}

Сврха и циљ овог рада је да укаже на стварне проблеме на које особа с посебним потребама може наићи приликом кретања у саобраћају. Изложени су технички нормативи (стандарди) којих се треба придржавати приликом пројектовања и изградње саобраћајних површина које користе сви учесници у саобраћају па и особе с посебним потребама. Приступачне саобраћајне површине и приступачни објекти у директној су повезаности са мобилношћу (броју путовања) особа с посебним потребама. У раду су предложене мере за отклањање баријера за неометано кретање особа с посебним потребама.
Главни задатак овог рада био је да се на основу анкетирања особа с одређеном врстом инвалидитеtа утврди број путовања особа с посебним потребама на основу врсте инвалидитета, сврхе (разлога) кретања, као и врсте превоза (начина кретања) у току радног и нерадног дана. Сви подаци су добијени реалним истраживањем методом анкетирања.

На основу добијених података може се утврдити која врста превоза се најчешће користи приликом обављања путовања, који је главни разлог кретања, у којој мери се одређене групе особа с инвалидитетом могу кретати, шта учинити да се њихово кретање олакша, побољша итд.

\section{7. ЛИТЕРЕТУРА}

[1] Човек и окружење: Семинар о основама универзалног дизајна/дизајна за све у планирању и изградњи простора, обликовању производа, информација и услуга (приступљено у јануару 2020. преко www.czuns.org)

[2] Европски концепт приступачности, Луксембург, 2008.

[3] Путеви Србије: Приручник за пројектовање путева, Београд, 2012. http://www.putevisrbije.rs/pdf/harmonizacija/prirucnik za_projektovanje_p uteva/SRDM5-7-pesacke-povrsine(120505-srb-

konacni).pdf (приступљено у јануару 2020.)

[4] Европски концепт приступачности - технички приручник, Луксембург, 2003.

[5] Cтратегија приступачности града Новог Сада 2012 - 2018, Град Нови Сад, 2012.

\section{Кратка биографија:}

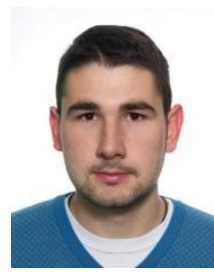

Боривој Сандић рођен је у Сремској Митровици 1994. године.

Завршио је Средњу саобраћајну школу "Пинки" у Новом Саду 2013. године. Дипломирао је на Факултету техничких наука септембра 2017. године. 